\title{
High risk sexually transmitted disease behaviour in Canada
}

NONI E MACDONALD, MD, FRCPC

\begin{abstract}
NE MACDONALD. High risk sexually transmitted disease behaviour in Canada. Can J Infect Dis 1991;2(Suppl A):18A-22A. High risk sexually transmitted disease (STD)/ human immunodeficiency virus (HIV) transmission behaviour appears to be the norm, not the exception, for most adolescents. The perception of STD/HIV risk and actual risk do not always match. The major motivating factor for condom use evident in adolescents was fear of pregnancy, not fear of the acquired immune deficiency syndrome or STDs. Other factors influencing decreased condom use included: embarrassment about buying condoms; difficulty discussing condoms with a prospective partner; use of oral contraceptives; belief that condoms interfere with sexual pleasure; low HIV knowledge; and, for women, a large number of sexual partners. Overall, females reported having had more STDs than males. Prostitutes, both male and female. reported the highest rates ( $45 \%$ and $68 \%$, respectively). Of the street youths studied, $16 \%$ reported having at least one prior STD diagnosis, compared to $9 \%$ of school dropouts and $5 \%$ of first year college students. The number of sexual partners and participation in anal intercourse strongly influenced the reported STD rate for street youths. STD/HIV risk reduction educational programs must be targeted and adapted to the cultural and social needs and resources of the different adolescent groups, particularly street youth. who are clearly a 'core' group for adolescent STD.
\end{abstract}

Key Words: Ans. Canadian youth, Sexual behaviour, Sexually transmitted disease

\section{Comportement sexuel à risque élevé de MTS au Canada}

RESUME: Plutôt qu'exceptionnels, les comportements sexuels qui exposcnt aux maladies transmises sexuellement (MTS) ou au virus d'immunodéficience humaine (VIH) sont caractéristiques de la plupart des adolescents canadiens. Leur perception des risques de MTS/VIH ne correspond pas toujours à la réalité. C'est la crainte d'une grossesse et non pas la peur du SIDA ou des MTS qui pousse surtout les adolescents à utiliser les préservatifs. D'autres facteurs expliquent qu'ils aient de moins en moins recours aux condoms: ils sont gênés de les acheter; ils éprouvent des difficultés à parler de leur usage avec un/une partenaire éventuel/le; les jeunes filles prennent des contraceptifs oraux; ils pensent que les condoms gâchent le plaisir sexuel; les jeunes sont mal informés au sujet du VIH; et, dans le cas des femmics, Ies partenaires sexuels sont nombreux. Dans l'ensemble, Ics adolescentes rapportent

Head, Division of Pediatric Infectious Disease. Children's I Iospital of Eastern Ontario, and Frofessor of Pediatrics and Microbiology, University of Ottawa, Ottawa, Ontario

Correspondence and reprints: Dr NE MacDonald, Division of Infectious Disease, Children's Iospital of Eastern Ontario, $40 \mathrm{l}$ Smuth Road. Ottawa. Ontario KIH $8 \mathrm{LI}$ 
un plus grand nombre de MTS que les adolescents. Les taux les plus élevés se trouvent chez les prostitués des deux sexes (hommes 45\%; femmes $68 \%$ ). Parmi les jeunes des rues interrogés, $16 \%$ rapportent au moins un diagnostic de MTS, alors que le pourcentage est de $9 \%$ chez les jeunes qui ont abandonné leurs ètudes et de $5 \%$ chez les collègiens en première année. Le nombre de partenaires sexuels et la participation au coït anal influerıcent fortement le taux rapportê de MTS chez les jeunes des rues. Les programmes éducatifs destinés à rêduire les risques de MTS/VIH doivent viser les divers groupes d'adolescents et être adaptés à leurs besoins socio-culturels et à leurs ressources - surtout en ce qui concerne les jeunes des rues. qui constituent un groupe particulièrement vulnérable aux MTS parmi les adolescents.

A LTHOUGH SEXUALL TRANSMITTED DISEASES (STDs) have been hyperendemic in Canada for years, the parameters of the epidemic have changed dramatically during the past decade (1). The rate of gonorrhea has significantly declined and there has been a major shift in the population at highest risk. Prior to the late 1980s, adult males had the highest rate of gonorrhea, followed distantly by adolescent females. By 1987, the rate of gonorrhea in adult males had dropped almost to the level of that for females aged 15 to 19 years (2) and by 1988, declined further (3). This shift in the age risk pattern and overall decline in gonorrhea were not spurious observations as the 1989 data are similar (4).

Canada is not alone in seeing marked changes in the gonorrhea epidemic. A parallel decline in the rate of gonorrhea and a shift in risk pattern have also been seen in the United States $(5,6)$. Again, adolescent females now predominate, but there are also major racial differences in rates which have widened sharply since 1984 when the incidence among blacks began to rise rapidly $(6,7)$.

\section{PUBLIC AWARENESS}

Experts have attributed the decline in gonorrhea in North America to intensified public health efforts along with the ageing of the 'baby boom' generation, and not to an overall increase in public awareness and concern about STDs $(7,8)$. The dramatic drop in the rate of gonorrhea among adult white males during this past decade is thought to be partly due to the widespread acceptance, particularly by homosexual men, that human immunodeficiency virus (HIV) risk is significantly increased during unprotected coitus with multiple partners. For this group, the message was poignantly reinforced early in the 1980 s when friends and lovers died from the acquired immune deficiency syndrome (NIDS). This led to a change in sexual practices, with a notable decrease in HIV risk behaviours. The added benefit was the dramatic decline in the group's rate of gonorrhea.

In contrast, despite the NIDS media bombard- ment, adolescent sexual practices have not changed much over this past decade, judging by their relatively stable rates of gonorrhea $(1,6)$. Canadian adolescents do not perceive themselves to be at high risk for AIDs and have not embraced safer sexual practices $(9,10)$. The 1988 'Canada Youth and AIDS Study, including 38,000 youths determined that the outcome of sexual intercourse that worries youths most is pregnancy (10) (Table 1). Although AIDs was the second major worry, fear of AIDS was not sufficient to influence sexual practices $(9,10)$. AIDS is perceived as a problem for people other than oncself (10).

Adolescents are not alone in their perception that AuDs is primarily a problem for homosexual males. A survey of Canadian adults in 1989 revealed similar findings (11). In response to the question "Which individuals or groups are more likely to become infected with the AIDs virus?", $63 \%$ of the respondents identified homosexual men; 11\%, intravenous drug abusers; 9\%, "promiscuous' people; 4\%, teenagers; and 2\%, prostitutes.

Unfortunately, the perception of STD/HIV risk and actual risk do not always match. For example, a study of STD prevalence among 50 adolescent prostitutes conducted in 1987 revealed that $40 \%$ were infected with gonorrhea, $46 \%$ with chlamydia, and 6\% with HIV (12). Despite these high STD rates, $70 \%$ of these adolescent prostitutes felt that their risk was no different than that of any other adolescent.

Thus, while the general public perceives Alls to be a serious problem, the only group to significantly modify its sexual behaviour is the one that has acknowledged its high HIV risk.

TABLE 1

Major concern about outcome of sexual intercourse

\begin{tabular}{lccc}
\hline & Pregnancy & AIDS & STD \\
\hline Grade 11 & $57 \%$ & $39 \%$ & $4 \%$ \\
College/university & $60 \%$ & $37 \%$ & $4 \%$ \\
\hline
\end{tabular}

AIDS Acquired immune deficiency syndrome; STD Sexually transmitted disease 


\section{ATITUDES AND RISKY SEXUAL BEHAVIOUR IN CANADIAN COLLEGE STUDENTS}

One of the reasons STDs other than AIDS are not perceived as serious by adolescents may be simply a lack of knowledge about STDs other than AIDS. For example, $85 \%$ of the first year college students surveyed in the 'Canada Youth and AIDS Study' did not know that the risks of serious consequences of STDs differ for men and women $(9,10)$. Furthermore, almost one-half (48.2\%) were unaware that STD infection can be asymptomatic and one-half did not know that genital herpes can be acquired during oral sex (48.3\%). Eighteen per cent were unaware that once an STD is contracted, it can be caught again. Only $45.8 \%$ knew that petroleum jelly is not a good lubricant to use with a condom. Clearly, the content of STD education programs needs to be upgraded.

Further analysis of the data from the "Canada Youth and AIDS Study' for the subset of first year college/university students who were younger than 25 years of age revealed that although many are coitally active, most do not practise safer sex (9). Overall, $74 \%$ of the males and $69 \%$ of the females had participated in sexual intercourse at least once, but consistent condom use was uncommon. Only $25 \%$ of the coitally active men and $16 \%$ of the women always used a condom. Unfortunately, condom use declined with increasing numbers of partners for women, and did not correlate with the number of sexual partners for men.

While few respondents were members of traditional HIV high risk groups, many reported behaviours known to increase risk of acquisition of HIV. One in five men $(21 \%)$ and one in 11 women $(9 \%)$ reported having had 10 or more sexual partners; of these, only $21 \%$ of the men and $7.5 \%$ of the women consistently used condoms (9). In other words, $79 \%$ and $92 \%$ of men and women, respectively, did not use condoms consistently. Almost $30 \%$ of these men and 35\% of these women had participated in anal intercourse, and $8 \%$ of men and $3 \%$ of women did so often.

The overall rate of reported previous STDs among the coitally active college students was $5.5 \%$, but as the number of partners increased there was a linear increase in reported STD rate among the men and an exponential increase among the women (9). For women with 10 or more partners, 24\% reported having had an STD diagnosed at least once compared to only $3 \%$ of women with one partner. For men, the corresponding rates of reported STDs were $11 \%$ and $1 \%$, respectively.

Furthermore, for the women, a complex interrelationship was noted between the number of sex- ual partners, condom use, oral contraceptive use and STD history (9). As the number of partners increased, the likelihood of oral contraceptive use increased, condom use declined and a history of previous STDs increased exponentially. These data confirm that fear of pregnancy, not fear of AIDS or STDs, is the major motivating factor for condom use among this group. Once fear of pregnancy is removed by the use of oral contraceptives, condom use rapidly declines.

Unfortunately, knowledge of HIV and/or STDs was not translated into safer sexual practices: there was no relationship between what the student knew and what he or she did (9). The factors that most influenced decreased condom use included: embarrassment about buying condoms; difficulty discussing condoms with prospective partner; use of oral contraceptives: the belief that condoms interfere with sexual pleasure; low HIV knowledge; and for women, a large number of sexual partners:

All of these factors should be amenable to change with appropriate educational programs (9,13-15).

Even if safer sexual practices can be increased among college and high school students, STDs will likely remain a major adolescent health problem, because street youth or adolescents who spend most of their time on city streets are at higher risk than college or high school students, and school dropouts who live at home are at intermediate risk (10-12).

As part of the 'Canada Youth and AIDS Study', 712 street youth in 10 urban centres across Canada were surveyed through face-to-face interviews (12). Of these, $14 \%$ were classified as prostitutes, $11 \%$ as drug abusers, $16 \%$ as young offenders, $38 \%$ as homeless, and $21 \%$ as unemployed. $\mathrm{Al}-$ though these categories are not mutually exclusive, inclusion in a category was based upon a youth's dominant link to the street. The mean age for the group was just over 17 years (range 15 to 20 ), and $55 \%$ were males.

While over $94 \%$ of street youth were coitally active, far more had multiple partners than did similarly aged grade 11 students or first year college/university students $(9,10)$. Almost onehalf ( $47 \%$ males, $41 \%$ females) of these youths had had at least 10 different sexual partners, and 16\% of the males and 18\% of the females had had at least 50 . In contrast, only $5 \%$ of male and $2 \%$ of female grade 11 students and $21 \%$ and $9 \%$, respectively, of first-year college students had had 10 or more partners. Among the prostitute subgroup of street youth, $71 \%$ of the females and $52 \%$ of the males had had over 100 different sexual partners. 
Overall, fewer than $26 \%$ of the street youth always used condoms, but there was a marked variation in consistency of use among the subgroups (unpublished data). Although both male and female prostitutes were the most likely to always use a condom, even in this subgroup, only $55 \%$ of the males and $58 \%$ of the females did so at all times. Drug abusers were not very consistent condom users, and unfortunately male drug abusers in particular often had large numbers of partners.

Other STD/HIV high risk behaviour was common among street youth. Approximately $23 \%$ of the street youth had participated in anal intercourse at least once and about 15\%, a few times or often (unpublished data). Although this rate is higher than that reported by first year college/ university students, it is quite similar to the rate reported by female school dropouts (unpublished data). Among street youth, prostitutes were the most likely of the subgroups to report anal intercourse (male 59\%, lemale 50\%), with male drug abusers also reporting a high rate (33\%).

Overall, 16\% of street youth reported having had an STD diagnosed at least once, compared to $9 \%$ of school dropouts and $5 \%$ of first year college/university students (unpublished data). For both male and female street youth, the number of sexual partners and participation in anal intercourse strongly influenced the reported STD rate. For all subgroups, females reported having had more STDs than males. Both male and female prostitutes reported the highest rates $(45 \%$ and $68 \%$, respectively).

\section{IMPLICATIONS FOR THE SPREAD OF STDS}

High risk STD and HIV transmission behaviours appear to be the norm, not the exception, for most adolescents regardless of whether they are street youth (9). For the general adolescent population, STD/HIV risk reduction educational programs must be changed to incorporate behaviorally relevant information that allows youth to assess personal risk objectively and to ascertain the best method of risk reduction within an individual social environment $(9,13,15)$. These programs must provide training in specific behavioral skills necessary for actually practising safer sex, such as: how to introduce the topic of safer sex in pre-intercourse discussion; how to negotiate condom use with a potentially unwilling partner; and how to exit unsafe sexual situations if a partner refuses to comply with safe sexual requests. Individuals must then be motivated to act on their knowledge of personal STD/HIV risk using behavioral risk reduction skills.

STDs are likely to remain a major problem for adolescents unless these types of intervention programs are implemented on a national scale. These programs, although similar in theme, must be targeted and adapted to the cultural and social needs and resources of different adolescent groups in different locales. Street youth, in particular, must become a major target for intervention because they are clearly a 'core' group for adolescent STDs (16). Intervention with this group will not be easy because it is difficult to gain access to them and they do not trust 'authority'. Furthermore, effecting change in the sexual practices of this group will be very difficult to achieve because of the role sex plays in street life. Sex is the one readily available commodity that street youth can use to buy shelter, food, drugs and alcohol. It is also a tool to combat loneliness and provides protection from street violence.

STD/HIV risk intervention programs for street youth must take into account their desperate inmediate needs for shelter, food and medical and psychological help for depression and alcohol and substance addiction. Programs must be sup ported by school reintegration and/or job training programs to help keep these youth off the street, as well as programs to prevent youth from falling into the street. STD/HIV risk behaviours are unlikely to change unless programs are comprehensive enough to meet the needs of this group and hence decrease the pressure to use sex as a survival commodity.

Delays in introducing targeted and behaviorally focused programs for street youth and all adolescents will only perpetuate the adolescent STD epidemic and escalate the possibility of a major adolescent HIV epidemic. Ignoring the adolescent STD problem will not make it go away and will only compound the tragedy. The time bomb of STD consequences is ticking. Without a change in STD/HIV risk behaviour, rates of pelvic inflammatory disease, ectopic pregnancy, cancer of the cervix and AlDs are expected to continue their dramatic upward spiral. Resources must be mobilized now because the personal, societal and financial costs of nonintervention are enormous.

\section{REFERENCES}

1. Trends in gonorrhea in Canadians 15-24 years of age, 1981-1988. Can Dis Weekly Rep 1989; 15:253-4.

2. Notifiable Diseases Annual Summary 1987. Ottawa: LCDC Health and Welfare Canada, 1988.

3. Notifiable Diseases Annual Summary 1988. Ottawa: LCDC Health and Welfare Canada, 1989.

4. Notifiable Diseases Annual Summary 1989. Ottawa: LCDC Health and Welfare Canada. 1990.

5. Cates W Jr. The epidemiology and control of sexually transmitted diseases in adolescents. Adolesc Med 1990;1:409-27. 
6. Cates W Jr. Teenagers and sexual risk taking: The best of times and the worst of times. J Adolesc Health $1991 ; 12: 84-94$.

7. Aral SO, Holmes KK. Sexually transmitted diseases in the AIDS era. Sci Am 1991;264:62-9.

8. Aral SO, Holmes KK. Epidemiology of sexually transmitted diseases. In: Holmes KK, Mardh PA. Sparling PF, Weisner PJ, eds. Sexually Transmitted Diseases. Toronto: McGraw Hill, 1990.

9. MacDonald NE, Wells GA, Fisher WA, et al. High-risk STD/HIV behavior among college students. JAMA 1990;263:3155-9.

10. King AJC, Beazley RP, Warren WK, Hankins CA, Roberston AS, Radford JL. Canada Youth and AIDS Study. Kingston, Ontario: Queen's University, 1988.

11. Ornstein M. AIDS in Canada. Knowledge, behavior, and attitudes of adults. Toronto: Institute for
Social Research, York University, 1989.

12. Radford JL, King AJC, Warren WK. Street Youth and AIDS. Kingston, Ontario: Queen's University. 1989.

13. Boyer CB. Psychosocial, behavioural, and educational factors in preventing sexually transmitted diseases. Adolesc Med 1990;1:597-613.

14. Ajzen I, Fishbein M. Understanding Attitudes and Predicting Social Behaviour. Englewood Cliffs, NJ: Prentice-Hall International Inc, 1980.

15. Kirscht JP. Preventive health behaviour, a revicw of research and issues. Health Psychol 1983:2:277-301.

16. Brunham RC, Plummer FA. A general model of sexually transmitted disease epidemiology and its implications for control. Med Clin North Am 1990; $74: 1339-52$. 


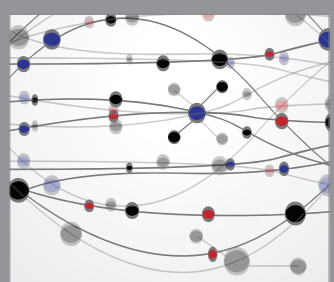

The Scientific World Journal
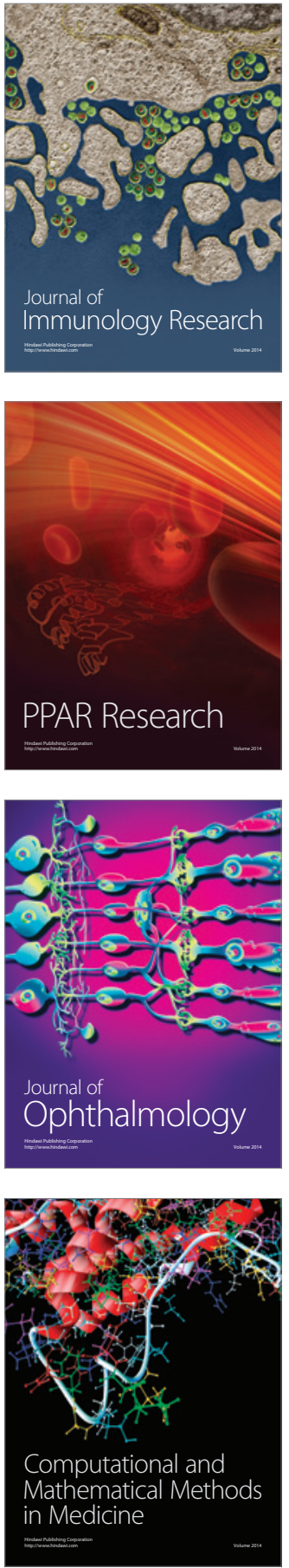

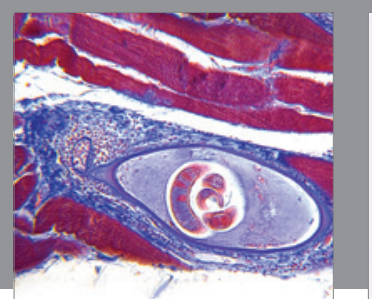

Gastroenterology Research and Practice

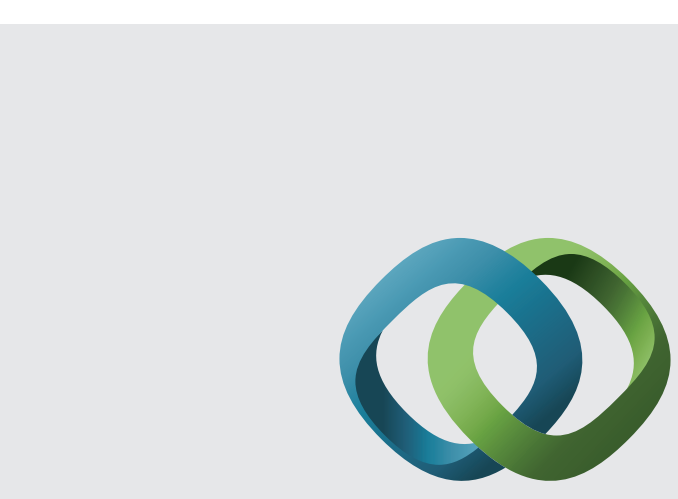

\section{Hindawi}

Submit your manuscripts at

http://www.hindawi.com
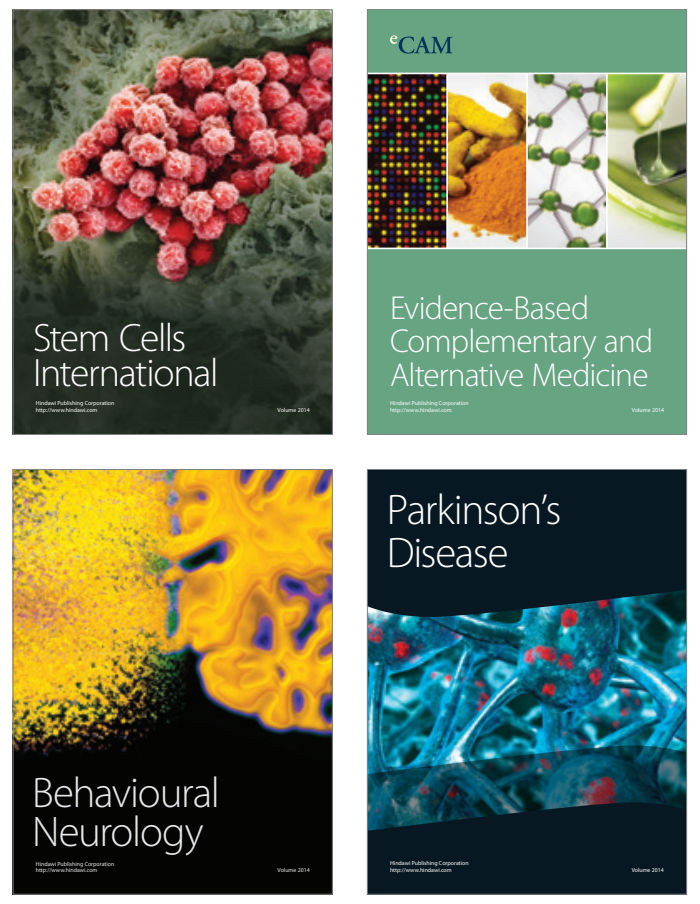
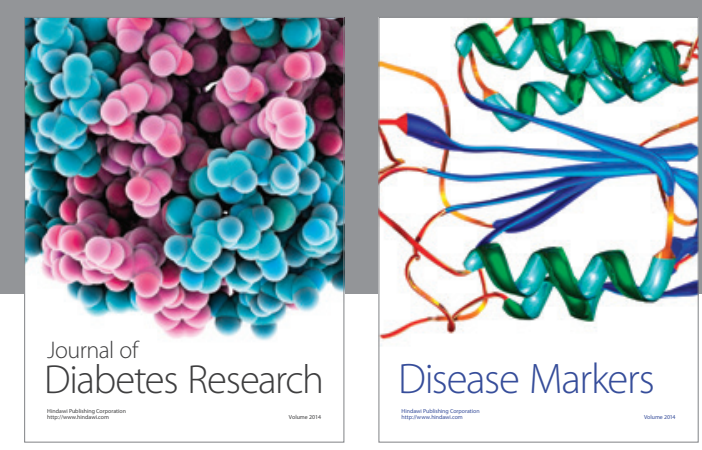

Disease Markers
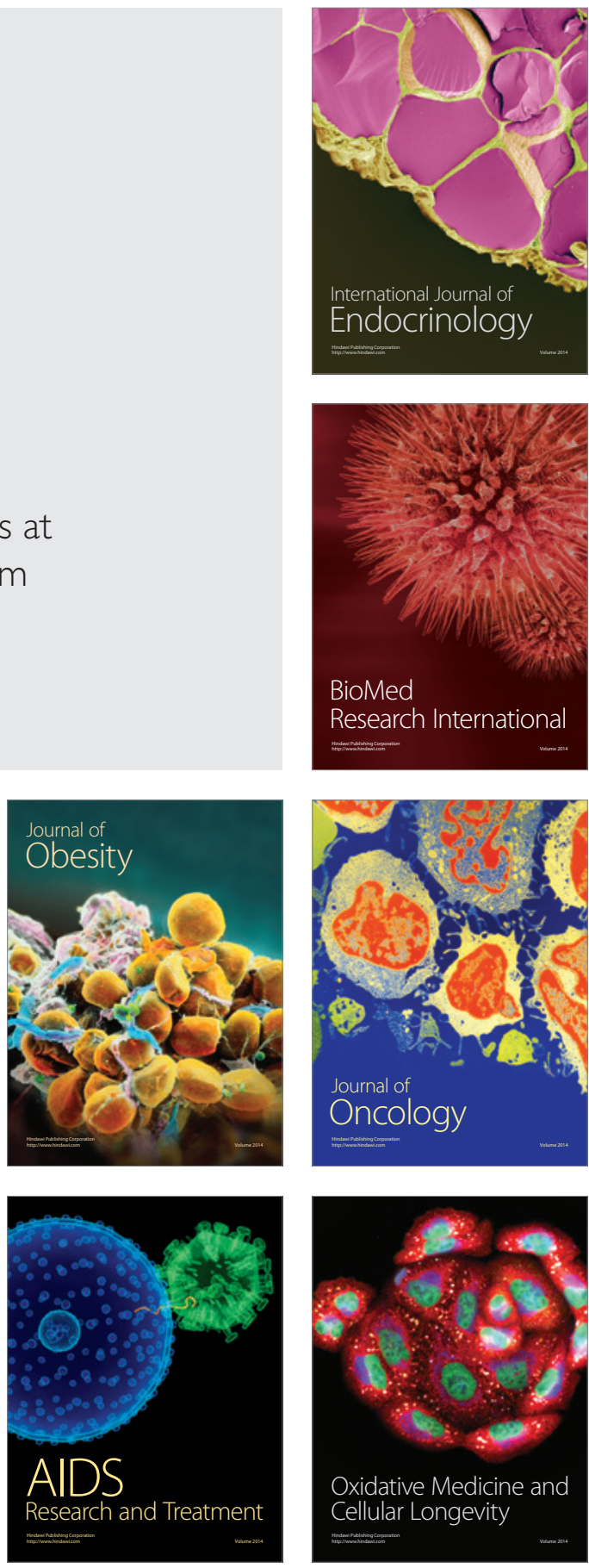